\title{
SEMANTIC VARIATION WITHIN THE CORPUS PAULINUM \\ LINGUISTIC CONSIDERATIONS CONCERNING THE RICHER \\ VOCABULARY OF THE PASTORAL EPISTLES ${ }^{1}$
}

Armin D. Baum

\begin{abstract}
Summary
It is generally conceded that the vocabulary of the Pastoral Epistles is substantially richer than the vocabulary of the other ten Paulines. Still, most of the hapax legomena of the Pastorals are close semantic neighbours to the vocabulary shared with the rest of the Corpus Paulinum. From a strictly linguistic perspective the semantic richness of the Pastorals indicates that in the process of composition their author had more time at his disposal than the author(s) of the other ten Pauline Epistles. Both in terms of syntax and semantics the style of the Pastoral Epistles simply has a greater affinity to written language than that of the rest of the Corpus Paulinum which more closely resembles (conceptual) orality. Therefore the historical question concerning the authorship of the Pastorals cannot be answered primarily on the basis of their stylistic peculiarities. In his often quoted study P. N. Harrison concluded that particularly for stylistic reasons the Pastorals cannot have been written by the same author as the rest of the Pauline epistles. However, in the light of recent linguistic research this conclusion appears to be questionable. Indeed, other criteria must be judged more significant than the semantic (and syntactic) peculiarities of the Pastorals.
\end{abstract}

1 Thanks are due to my colleague Dr H. von Siebenthal for his linguistic advice, to C. Ziegert (Dip. Math.) for his revision of the statistical data and to my assistant $\mathrm{Ph}$. Bartholomä and my colleague Dr J. White for their help with the English version of this paper. 
The stylistic peculiarities of the Pastoral Epistles have been described in great detail for over a hundred years. Within German-speaking scholarship a work by H. J. Holtzmann published in 1880 has been of primary importance. In this monograph he dedicates one chapter to the style of these three Paulines that have been disputed since the days of Schleiermacher. ${ }^{2}$ Of similar significance within English-speaking Pauline scholarship is the more recent and thorough work of P. N. Harrison. ${ }^{3}$ The findings presented by Holtzmann and especially Harrison have been supplemented (and modified) by subsequent studies.

Harrison employed a unique method for displaying his results in his text of the Pastoral Epistles. All Greek words that also occur in the other ten Paulines are in normal print, whereas words that are used only in the Pastorals appear in colour (printed here in bold). Additionally, he has underlined (and thus highlighted) 'the extraordinary number of phrases ... which coincide more or less closely ... with Paul's own most characteristic expressions in the ten epistles' (Appendix IV): 4

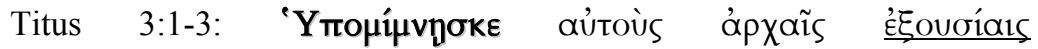

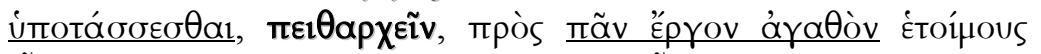

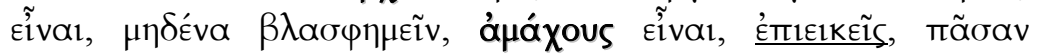

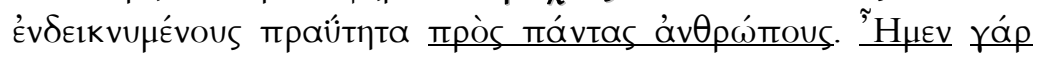

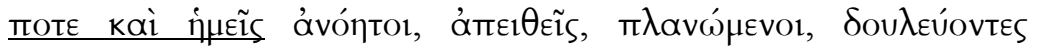

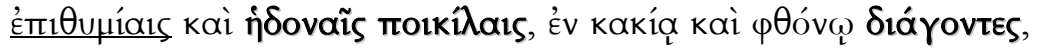

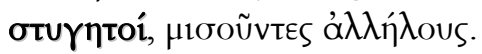

In the present study I limit myself to one aspect of stylistic analysis, namely the vocabulary of the Pastoral Epistles. What follows in section 1 are some further considerations relevant to the issue at hand. In section 2 I offer a new explanatory model for discussion.

\section{The Vocabulary of the Pastoral Epistles}

Since the time of Harrison, the statistical data concerning the peculiarities of the vocabulary of the Pastoral Epistles have been repeatedly collected and frequently discussed. Taking these collections

2 H. J. Holtzmann, Die Pastoralbriefe, kritisch und exegetisch behandelt (Leipzig: Engelmann, 1880): 84-118: 'Schreibweise und Sprachgebrauch' (chapter 7).

3 P. N. Harrison, The Problem of the Pastoral Epistles (London: OUP, 1921).

4 Harrison, The Problem of the Pastoral Epistles, 87-93, 185-98. 
as a starting point (1:1 und 1:2) I initially focus on the relationship between the distinctive vocabulary (Sondergutvokabular) of the Pastoral Epistles and the vocabulary of the other ten Paulines (1:3). Subsequently, on the basis of Paul's Epistle to Titus, I try to delineate its semantic relationship to the ten Paulines as precisely as possible $(1: 4)$.

\subsection{The Distinctive Vocabulary of the Pastoral Epistles}

The following data have been gathered from the 'Bible Works GNT Morphology Database'. ${ }^{5}$ They correspond extensively to those presented by M. B. O'Donnell. ${ }^{6}$ Differences with the results of R. N. Harrison $^{7}$ and R. Morgenthaler ${ }^{8}$ are mostly due to the fact that the latter worked with older editions of the New Testament and also did not consider all proper nouns. On the whole, however, resulting statistical discrepancies are minor and do not affect the results.

The Corpus Paulinum contains thirteen letters. These thirteen letters contain a total of 32,408 words (columns 1-2). The entire vocabulary stock of the Corpus Paulinum amounts to a total of 2,621 words. Each letter contains a subset of this vocabulary stock. In the table below, the thirteen Paulines are listed according to their length. This arrangement shows that the semantic inventory of the letters is generally proportionate to their length (column 2). When one excludes the Pastorals the relationship between the other ten Paulines is, in fact, strictly proportional: the longer a letter, the more extensive its vocabulary. This pattern is broken by the Pastorals. Although they exhibit the similar relationships of proportionality among themselves, the vocabulary stock of the Pastoral Epistles is greater than that of the non-Pastoral Paulines of comparable length. In other words:

5 Bible Works for Windows Version 6.0 (Big Fork: Hermeneutika, 2003).

6 'Linguistic Fingerprints of Style by Numbers? The Use of Statistics in the Discussion of Authorship of New Testament Documents', Linguistics and the New Testament: Critical Junctures (JSNT.S 168; ed. by S. E. Porter and D. A. Carson; Sheffield: Academic, 1999): 206-62, here 233-34. O'Donnell presents a careful overview of the linguistic-statistical studies on the Corpus Paulinum in the twentieth century. For more details about the history of research cf. also K. J. Neumann, The Authenticity of the Pauline Epistles in the Light of Stylostatistical Analysis (SBL.DS 120; Atlanta: Scholars, 1990): 23-114 and A. E. Bird, 'The Authorship of the Pastoral Epistles - Quantifying Literary Style', RTR 56 (1997): 118-37.

7 Harrison, The Problem of the Pastoral Epistles, 158-59.

8 R. Morgenthaler, Statistik des neutestamentlichen Wortschatzes (Zürich: Gotthelf, $\left.{ }^{3} 1982\right): 164$. 
1 Timothy has a larger vocabulary than Philippians, Galatians, and Ephesians, although it is shorter than any one of these three letters.

Semantic Inventory and Vocabulary in the Corpus Paulinum

\begin{tabular}{lcccccc}
\hline & $\begin{array}{c}\text { Semantic } \\
\text { Inventory } \\
\text { (tokens) }\end{array}$ & (types) & $\begin{array}{r}\text { Words occurring in } \\
\text { more than one letter } \\
\text { (shared words) }\end{array}$ & $\begin{array}{c}\text { Words occurring in } \\
\text { only one letter } \\
\text { (single letter words) }\end{array}$ \\
\hline Rom. & 7111 & 1055 & 781 & $74 \%$ & 274 & $26 \%$ \\
1 Cor. & 6830 & 951 & 706 & $74 \%$ & 245 & $26 \%$ \\
2 Cor. & 4477 & 779 & 602 & $77 \%$ & 177 & $23 \%$ \\
Eph. & 2422 & 527 & 443 & $84 \%$ & 84 & $16 \%$ \\
Gal. & 2230 & 520 & 430 & $83 \%$ & 90 & $17 \%$ \\
Phil. & 1629 & 440 & 365 & $83 \%$ & 75 & $17 \%$ \\
1 Tim. & 1591 & 535 & 406 & $76 \%$ & 129 & $24 \%$ \\
Col. & 1582 & 429 & 365 & $85 \%$ & 64 & $15 \%$ \\
1 Thess. & 1481 & 362 & 327 & $90 \%$ & 35 & $10 \%$ \\
2 Tim. & 1238 & 451 & 350 & $78 \%$ & 101 & $22 \%$ \\
2 Thess. & 823 & 249 & 228 & $92 \%$ & 21 & $8 \%$ \\
Titus & 659 & 298 & 249 & $84 \%$ & 49 & $16 \%$ \\
Phlm. & 335 & 140 & 130 & $93 \%$ & 10 & $7 \%$ \\
Total & 32408 & 2621 & 1267 & & 1354 & \\
& & & & & & \\
Past. & 3488 & 892 & 561 & $63 \%$ & 331 & $37 \%$ \\
1 Tim. & 1591 & 535 & 361 & $67 \%$ & 174 & $33 \%$ \\
2 Tim. & 1238 & 451 & 317 & $70 \%$ & 134 & $30 \%$ \\
Titus & 659 & 298 & 215 & $72 \%$ & 83 & $28 \%$ \\
\hline
\end{tabular}

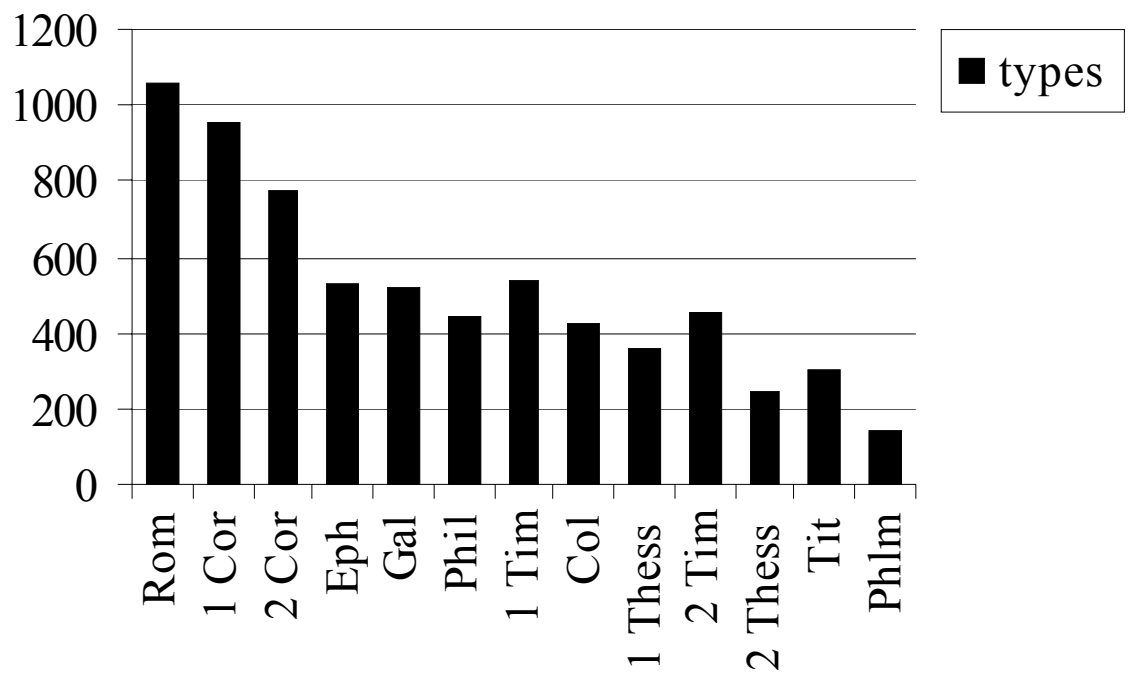


2 Timothy uses more words than 1 Thessalonians, Colossians and Philippians, although it is shorter than these letters. And Titus has a richer vocabulary stock than 2 Thessalonians, although it is considerably shorter. The following diagram makes this quite clear.

With regard to the relationship between semantic inventory and vocabulary as seen in the other ten letters of the Corpus Paulinum, the Pastoral Epistles would only fit in if their respective word counts were significantly smaller. Instead of 535 different words, 1 Timothy should only contain about 435 . We would expect 2 Timothy to contain about 350 different words, rather than 451 . And in Titus there should only be about 235 instead of the now 298 different words. What the numbers regarding the vocabulary of the Pastoral Epistles would need to look like in order to correspond to those of the ten other Paulines is displayed in the lower half of the table below ('Semantic Inventory and Vocabulary in the Pastoral Epistles').

Let us return to the table from which we started regarding the 'Semantic Inventory and Vocabulary in the Corpus Paulinum': 1,267 words of the Pauline vocabulary stock of 2,621 words, i.e. approximately one half, are used in more than one of Paul's letters (columns 4-5). The longer the letter, the smaller the percentage of these shared words with respect to its total vocabulary stock. Thus Philemon shares ninety-three percent of its vocabulary with at least one other letter, whereas the slightly longer 2 Thessalonians shares only ninetytwo percent and so on. In this regard, we find a continuous progression within the ten letters of the Corpus Paulinum. Within the three Pastoral Epistles, the number of shared words in the total vocabulary stock is also inversely proportional to its length. However, the number of the shared words in the vocabulary stock of each letter is generally much lower than in the other ten Paulines. All this is to say that the percentage of the shared words in the Pastoral Epistles (highlighted in grey) diverges from the verifiable pattern of the other letters as well.

These results correspond to the data concerning words that occur in only one letter of the Corpus Paulinum (columns 6-7). Each of Paul's letters contains a fair number of words that do not occur in any of the other twelve letters. One may designate those words as the distinctive vocabulary of each Pauline letter. The share of these single letter words in the vocabulary of any particular letter increases in proportion to the length of the letter. This increase is not only verifiable in the ten letters, but also in the Pastoral Epistles. Within the Pastoral Epistles, however, 
the share of distinctive words in the particular vocabulary is much higher compared to the other letters in the Corpus Paulinum. While the share of distinctive words in the vocabulary of Philippians is only seventeen percent, distinctive words in 1 Timothy (which is about the same length as Phil.) make up twenty-four percent of the total. Similar observations can be made when we compare 2 Timothy and Titus to letters of about the same length.

If one treats the three Pastoral Epistles as one letter, the results are similar (cf. the lower part of the above table 'Semantic Inventory and Vocabulary in the Corpus Paulinum'). Although such a letter would not even be half as long as Romans, it would have a much higher share of single letter words (that only occur in the three Pastoral Epistles) than Romans.

In order to adjust the vocabulary of the Pastoral Epistles to the one of the other ten Paulines one would have to slightly reduce the number of the shared words. The number of the Pastoral letter words, however, would need to be considerably lower. Instead of 129, 1 Timothy should only have seventy Pastoral-letter words, 2 Timothy only forty-two instead of 101 and Titus nineteen instead of forty-nine. A letter made up of the three Pastoral Epistles should only contain 107 words not used in the other ten Paulines, instead of the actual 331. These theoretical numbers (presented between parentheses in the lower part of the table below) may convey an impression as to how the vocabulary of

\section{Semantic Inventory and Vocabulary in the Pastoral Epistles}

\begin{tabular}{lcccccc}
\hline & $\begin{array}{c}\text { Semantic } \\
\text { Inventory } \\
\text { (tokens) }\end{array}$ & $\begin{array}{c}\text { Vocab. } \\
\text { (types) }\end{array}$ & \multicolumn{2}{c}{$\begin{array}{c}\text { Words occurring in } \\
\text { more than one letter } \\
\text { (shared words) }\end{array}$} & \multicolumn{2}{c}{$\begin{array}{c}\text { Words occurring in } \\
\text { only one letter } \\
\text { (single letter words) }\end{array}$} \\
\hline 1 Tim. & 1591 & 535 & 406 & $76 \%$ & 129 & $24 \%$ \\
2 Tim. & 1238 & 451 & 350 & $78 \%$ & 101 & $22 \%$ \\
Titus & 659 & 298 & 249 & $84 \%$ & 49 & $16 \%$ \\
Past & 3488 & 892 & 561 & $63 \%$ & 331 & $37 \%$ \\
& & & & & & \\
(1 Tim.) & 1591 & $(435)$ & $(365)$ & $(84 \%)$ & $(70)$ & $(16 \%)$ \\
(2 Tim.) & 1238 & $(350)$ & $(308)$ & $(88 \%)$ & $(42)$ & $(12 \%)$ \\
(Titus) & 659 & $(235)$ & $(216)$ & $(92 \%)$ & $(19)$ & $(8 \%)$ \\
(Past) & 3488 & $(562)$ & $(455)$ & $(81 \%)$ & $(107)$ & $(19 \%)$ \\
\hline
\end{tabular}

the Pastoral Epistles differs from that of the other ten Paulines. The share of distinct words in the vocabulary of the Pastoral Epistles is 
about twenty percent higher than what one would expect when compared to the distinct words within the ten other Paulines.

\subsection{The Share of Distinct Words in the Semantic Inventory of the Pastoral Epistles}

Those words of the Pauline vocabulary stock that only occur in one Pastoral Epistle or only in this epistolary group, are for the most part not used only once, but twice or more within these letters. The following table shows that the 129 distinctive words of 1 Timothy occur a total of 149 times and the 331 distinctive words of the Pastoral Epistles occur 460 times in these three letters (columns 4 and 6).

If one relates these data about the frequency of distinctive words to the semantic inventory of each particular letter, one can calculate the percentage of distinctive words within that letter. For example, the text of 1 Timothy contains a total of nine percent distinctive words, both 2 Timothy and Titus have eight percent. If one combines the Pastoral Epistles, the 460 distinctive words account for thirteen percent of the total of 3,488 words (column 7).

These data may be easily compared to the corresponding numbers for other Pauline letters of similar length (cf. the lower part of the following table). While the share of distinctive words in the text of 2 Timothy amounts to eight percent, the share of distinctive words in the text of the only slightly longer 1 Thessalonians adds up to only three percent (column 7). Taken as a whole, the share of distinctive words in the semantic inventory of the Pastoral Epistles is about five percentage points higher than within the ten other Paulines.

Overall, the vocabulary of the three Pastoral Epistles is therefore considerably richer than the vocabulary of the other ten Paulines. And the semantic inventory of the Pastoral Epistles features a much higher percentage of distinctive words than the rest of the Pauline letters. ${ }^{9}$ Those exegetes who deny these stylistic peculiarities of the Pastorals ${ }^{10}$ are certainly mistaken in this respect.

9 For further linguistic-statistical observations that affirm the special character of the Pastorals (which we have substantiated by means of the distinctive vocabulary) $\mathrm{cf}$. K. Grayston and G. Herdan, 'The Authorship of the Pastorals in the Light of Statistical Linguistics', NTS 6 (1959-60): 1-15; D. L. Mealand, 'The Extent of the Pauline Corpus: A Multivariate Approach', JSNT 59 (1995): 61-92.

10 E.g. J. J. O'Rourke, 'Some Considerations about Attempts at Statistical Analysis of the Pauline Corpus', $C B Q 35$ (1973): 483-90, here 483: 'the Pastorals do not stand out from the rest of the Paulines by the reason of the peculiarity of their vocabulary'; T. A. 
TYNDALE BULLETIN 59.2 (2008)

Distinctive Vocabulary and Distinctive Semantic Inventory in the Corpus Paulinum

\begin{tabular}{lcccccc}
\hline & $\begin{array}{l}\text { Vocab. } \\
\text { (types) }\end{array}$ & $\begin{array}{c}\text { Semantic } \\
\text { Inventory } \\
\text { (tokens) }\end{array}$ & \multicolumn{2}{c}{$\begin{array}{c}\text { Distinctive } \\
\text { Vocabulary } \\
\text { (types) }\end{array}$} & \multicolumn{2}{c}{$\begin{array}{c}\text { Distinctive } \\
\text { Semantic Inventory } \\
\text { (tokens) }\end{array}$} \\
\hline 1 Tim. & 535 & 1591 & 129 & $24 \%$ & 149 & $9 \%$ \\
2 Tim. & 451 & 1238 & 101 & $22 \%$ & 105 & $8 \%$ \\
Titus & 298 & 659 & 49 & $16 \%$ & 53 & $8 \%$ \\
Past & 892 & 3488 & 331 & $37 \%$ & 460 & $13 \%$ \\
& & & & & & \\
Col. & 429 & 1582 & 64 & $15 \%$ & 69 & $4 \%$ \\
1 Thess. & 362 & 1481 & 35 & $10 \%$ & 39 & $3 \%$ \\
2 Thess. & 249 & 823 & 21 & $8 \%$ & 24 & $3 \%$ \\
2 Cor. & 779 & 4477 & 177 & $23 \%$ & 243 & $5 \%$ \\
\hline
\end{tabular}

\subsection{The Semantic Richness of the Pastoral Epistles}

With regard to most of the distinctive words of the Pastoral Epistles, one may easily identify semantic neighbours within the other ten Pauline Epistles (in which those words do not occur). In certain contexts these semantic neighbours correspond to the same real-world referents. In what follows we will also use the term (pragmatic) synonyms. In the relevant contexts these synonyms are interchangeable with the distinctive words used in the Pastoral Epistles. For compiling such a list of synonyms the lexicon edited by J. P. Louw and E. A. Nida is especially helpful since it arranges the New Testament vocabulary according to 'semantic domains'. ${ }^{11}$

In many cases the Pastoral Epistles use two or more (roughly) synonymous words in order to describe an entity for which the other ten Paulines only use one word. For instance, whereas the ten Paulines

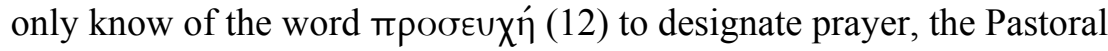

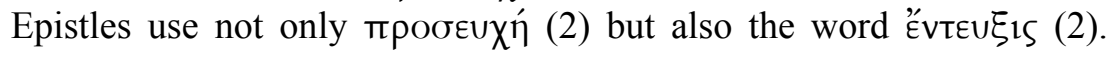
This richness of (pragmatic) synonyms is especially striking when it

Robinson, 'Grayston and Herdan's "C" Quantity Formula and the Authorship of the Pastoral Epistles', NTS 30 (1984): 282-93, here 286: 'the marked difference between the "C" quantities of the Pastorals and of the Paulines all but vanishes when each epistle is considered individually'; E. Linnemann, 'Echtheitsfragen und Vokabelstatistik', JETh 10 (1996): 87-109, here 97: ' ... that the Pastoral Epistles are not fundamentally different from the other Pauline letters'.

11 Greek-English Lexicon of the New Testament Based on Semantic Domains (2 vols.; New York: UBS, 1988). 
comes to adjectives. In addition to ö $\gamma 105(72 / 4)$ the Pastorals also use iєротрєпи́s (0/1) and óoıs (0/2). ${ }^{12}$ For the semantic domain 'good' the Pastorals are familiar with up to fifteen Greek adjectives.

Besides those instances in which the Pastoral Epistles adopt a word also used in the other ten Paulines and supplement it with synonyms, there are other cases in which the Pastoral Epistles use a different word than the one attested in the rest of Paul's letters. Instead of $\pi \lambda \alpha$ vos

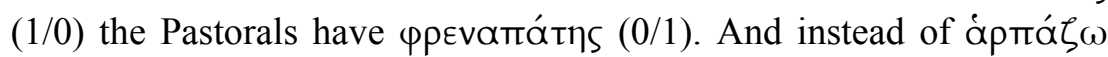

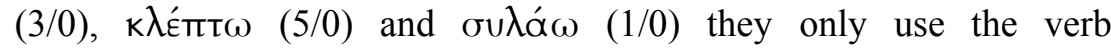
voopí̧онаi (0/1).

As a general rule the following is true: For each basic form of a word in the Pastorals one may find the basic form of another single word as a synonym in the other ten Paulines. Sometimes, however, not just single words, but phrases comprised of several words are synonymous. Besides $\delta i \grave{\alpha}$ toũto (10/2) and toútou Xápıv (2/1) the

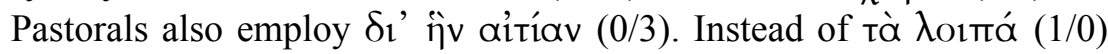
the Pastorals use tà $\lambda \varepsilon i ́ \pi$ tovta (0/1). Titus contains eighty-three words that occur only in the Pastoral Epistles. In the list below numbers denote the frequency of the particular word within Titus. Those fortynine words that occur in Titus only are marked with an asterisk:

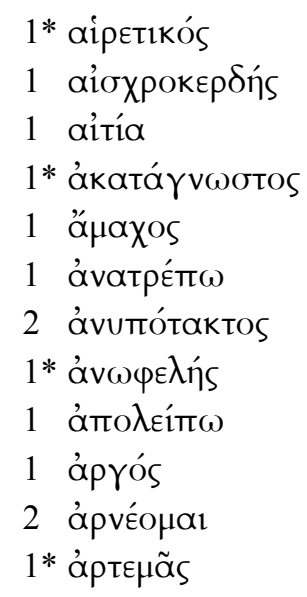

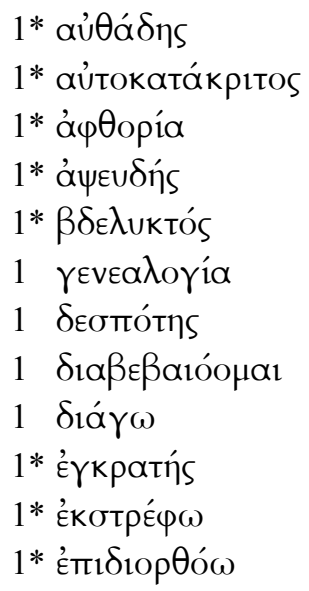

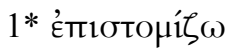

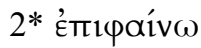

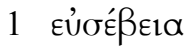

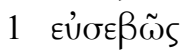

$1 * \zeta \eta v a ̃$ s

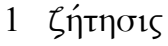

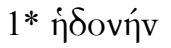

$1 *$ Anpíov

$1 *$ ieporpertís

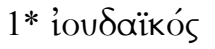

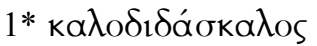

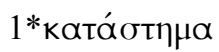

12 The number in front of the slash names the frequency of a word in the ten Paulines, the number after the slash names the frequency of the same word within the Pastoral Epistles. 


\begin{tabular}{|c|c|}
\hline & 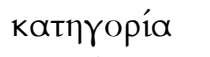 \\
\hline & 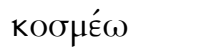 \\
\hline & кобн1кós \\
\hline & кри́s \\
\hline & кри́тп \\
\hline & $\lambda$ हiाt $\omega$ \\
\hline & 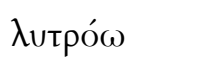 \\
\hline & нартирía \\
\hline & 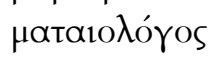 \\
\hline & 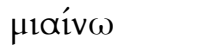 \\
\hline & $\mu \tilde{\text { Oos }}$ \\
\hline & 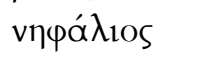 \\
\hline & vikómo $\lambda_{1 S}$ \\
\hline & voн1kós \\
\hline & $\operatorname{vo\sigma } \varphi i \zeta \omega$ \\
\hline & oikouprós \\
\hline
\end{tabular}

\begin{tabular}{|c|c|}
\hline & óprínos \\
\hline & öoros \\
\hline & $\pi \alpha \lambda i \gamma \gamma \in v \in \sigma i ́ \alpha$ \\
\hline & 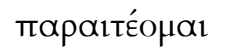 \\
\hline & та́polvos \\
\hline & $\pi \varepsilon 1 \theta \propto \rho \chi \chi^{\prime} \omega$ \\
\hline & 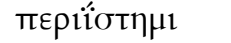 \\
\hline & 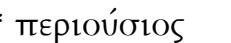 \\
\hline & $\pi \varepsilon \rho і \varphi \rho \operatorname{lov}^{\prime} \omega$ \\
\hline & $\pi \lambda \eta ́ k$ זाई \\
\hline & 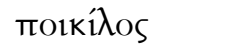 \\
\hline & трєбßútєро \\
\hline & $\pi \rho \in \sigma \beta \tilde{\tau} \tau ו s$ \\
\hline & $\pi \rho \sigma^{\prime} \chi \omega$ \\
\hline & 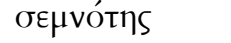 \\
\hline & otuY‡tós \\
\hline
\end{tabular}

$1 *$ owtípios

$1 * \sigma \omega \varphi p o v i ́ \zeta \omega$

$1 * \sigma \omega \varphi p o ́ v \omega s$

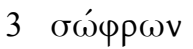

4 ùráivw

$1 *$ ưrins

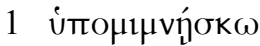

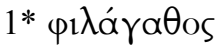

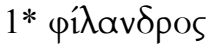

1*

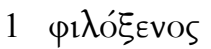

1* p1 $\lambda$ ótekvos

$1 *$ ppevará́tis

$1 *$ ppovtíl $\omega$

$1 \dot{\omega} \varphi \lambda^{\prime} \lambda_{\text {но }}$

The search within the other ten Paulines for semantic neighbours or pragmatic synonyms that match the distinctive words of the Pastoral Epistles used in Titus yields the following results: For more than seventy out of the total of eighty-three distinctive words one can easily find synonyms within the rest of Paul's letters. Those words used in the Corpus Paulinum but only attested within the Pastoral Epistles (i.e. the distinctive words of the Pastoral Epistles) are listed in bold print in the middle column of the following table. Those words not printed in bold are therefore synonyms taken from the corresponding 'semantic domain' according to Louw-Nida. The numbers in the first two columns indicate how frequently a word occurs in the ten Paulines or the three Pastorals respectively. The abbreviation 'Tit' indicates which of the words printed in bold belongs to the eighty-three distinctive words of the Pastorals that are actually attested in Titus. Those words in the middle column which belong to the forty-nine single letter words only attested in Titus are marked with an asterisk. The English translations are taken from Louw-Nida's Greek-English Lexicon of the New Testament Based on Semantic Domains. The synonymous Greek words are in alphabetical order within each semantic domain. The semantic domains are arranged by the alphabetical order of the first distinctive word (in bold print). 
BAUM: Semantic Variation in the Corpus Paulinum

\begin{tabular}{|c|c|c|}
\hline 10 Paulines & 3 Pastoral Epistles & \\
\hline ávaбтрофи́ 2 & 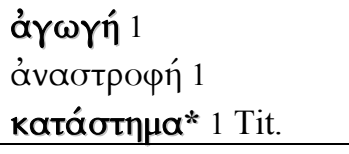 & $\begin{array}{l}\text { behaviour } \\
\text { behaviour } \\
\text { conduct, behaviour }\end{array}$ \\
\hline 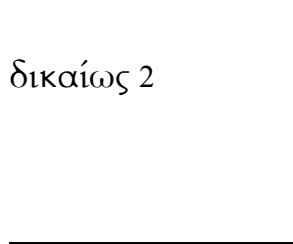 & 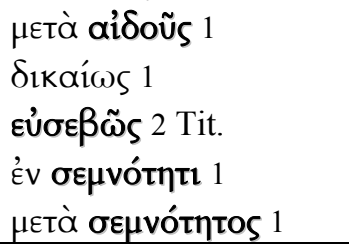 & $\begin{array}{l}\text { with modesty, respect } \\
\text { right } \\
\text { religious, devoted } \\
\text { with propriety, dignity, respect } \\
\text { with propriety, dignity, respect }\end{array}$ \\
\hline & 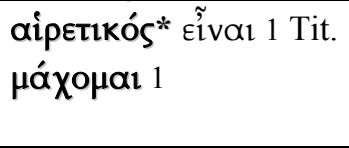 & $\begin{array}{l}\text { to be divisive } \\
\text { to clash severely, struggle, fight } \\
\text { to be given to arguing }\end{array}$ \\
\hline$\pi \lambda$ EovéktךS 4 & 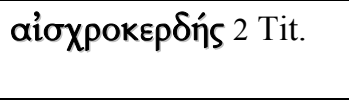 & $\begin{array}{l}\text { greedy for material profit } \\
\text { greedy person, covetous person }\end{array}$ \\
\hline $\begin{array}{l}\text { Si⿱亠̀ тoũto } 10 \\
\text { toútou Xápıv } 2 \\
\end{array}$ & 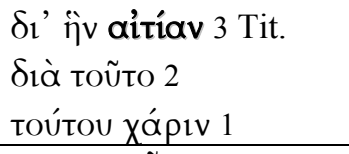 & $\begin{array}{l}\text { therefore, for this reason } \\
\text { therefore, for this reason } \\
\text { therefore, for this reason }\end{array}$ \\
\hline 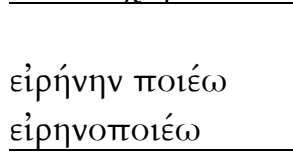 & 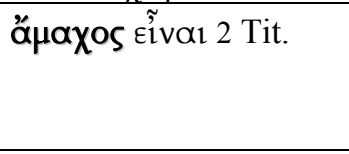 & $\begin{array}{l}\text { to be peaceful } \\
\text { to make peace } \\
\text { to make peace }\end{array}$ \\
\hline 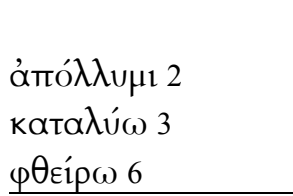 & 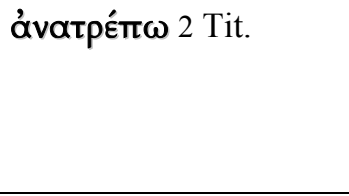 & $\begin{array}{l}\text { to turn over, upset, overturn } \\
\text { to destroy, cause destruction } \\
\text { to tear down, destroy } \\
\text { to ruin, destroy }\end{array}$ \\
\hline 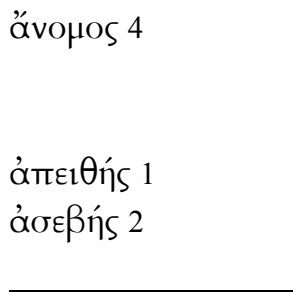 & 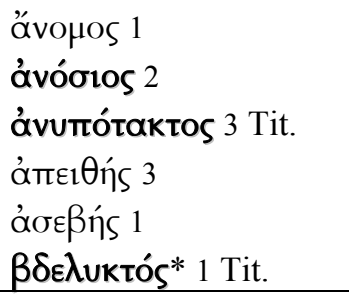 & $\begin{array}{l}\text { lawless } \\
\text { impious, unholy } \\
\text { disobedient, not subject to } \\
\text { disobedient } \\
\text { ungodly } \\
\text { abhorrent, detested }\end{array}$ \\
\hline 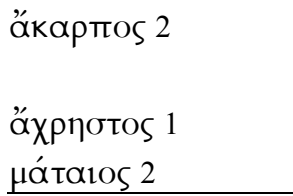 & 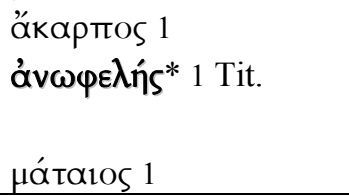 & $\begin{array}{l}\text { without fruit, useless } \\
\text { of no special benefit } \\
\text { useless } \\
\text { futile, lacking }\end{array}$ \\
\hline
\end{tabular}




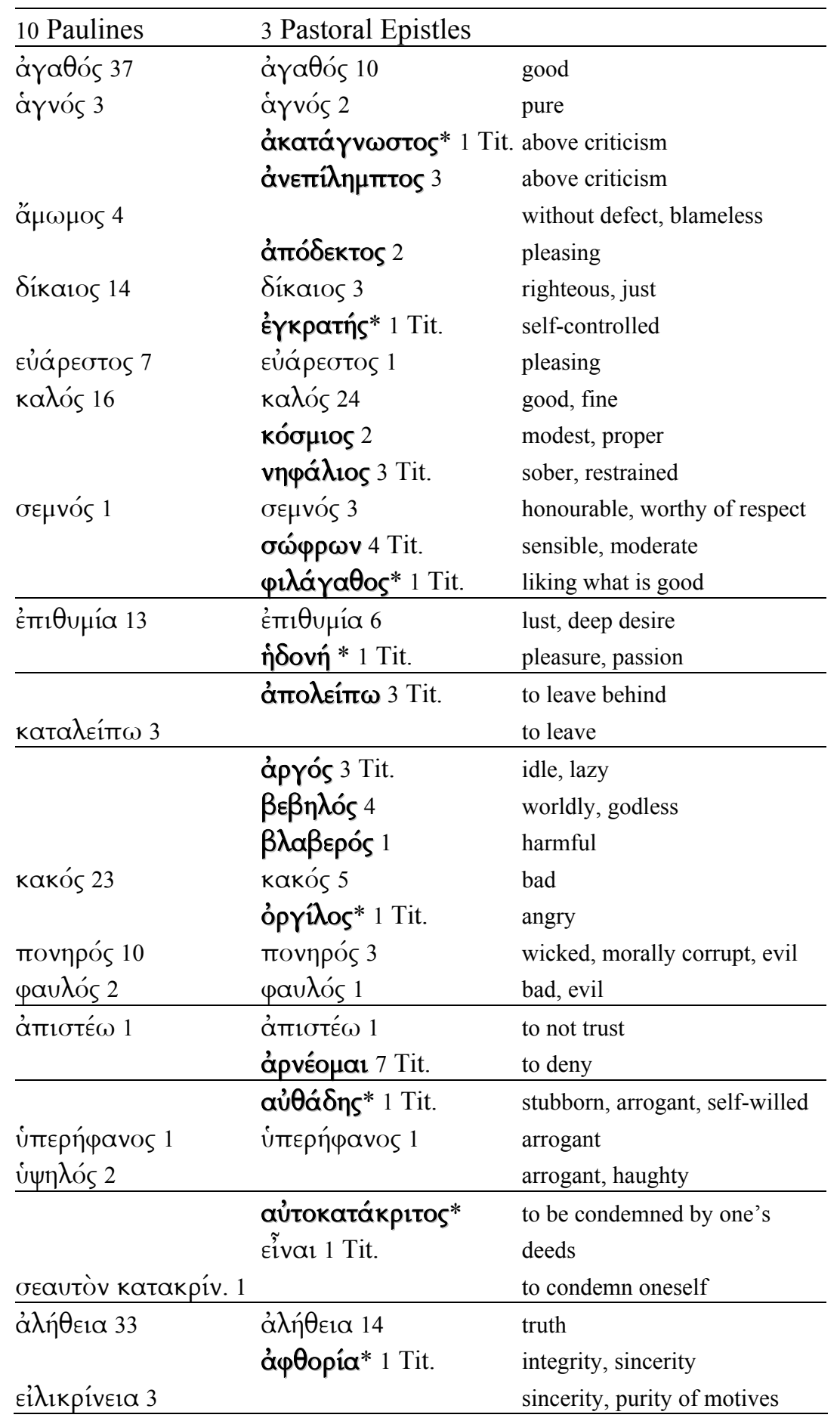


BAUM: Semantic Variation in the Corpus Paulinum

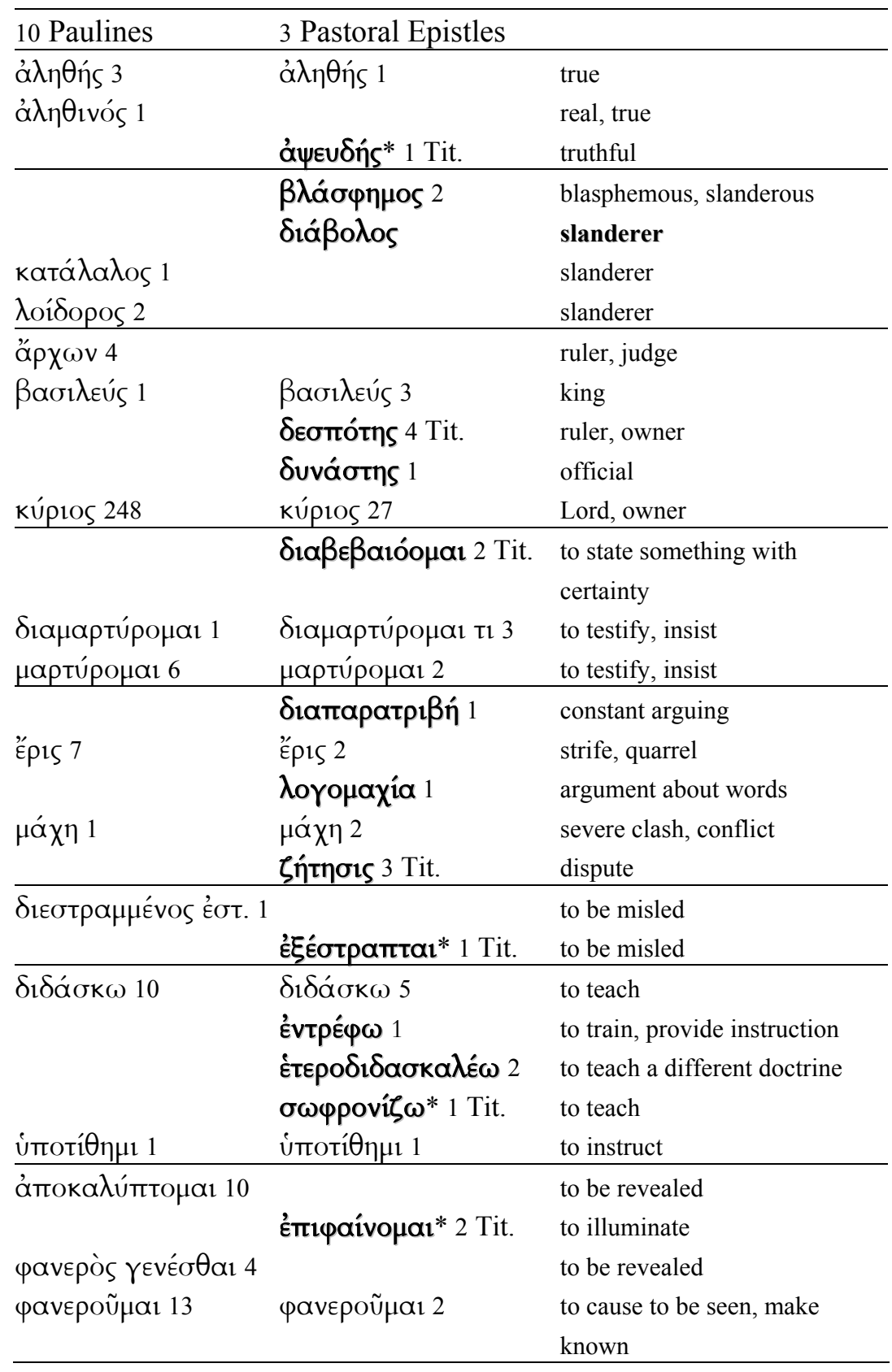




\begin{tabular}{|c|c|c|}
\hline 10 Paulines & 3 Pastoral Epistles & \\
\hline & 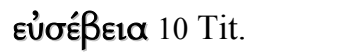 & religion, piety \\
\hline \multirow[t]{2}{*}{ 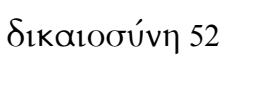 } & 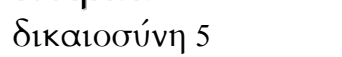 & justice \\
\hline & $\theta \varepsilon O \sigma \varepsilon ́ \beta \varepsilon 1 \alpha 1$ & religion \\
\hline 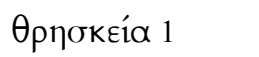 & & religion \\
\hline 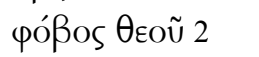 & & fear of God \\
\hline фóßos kupíou 1 & & fear of the Lord \\
\hline \multirow[t]{3}{*}{ ár } & 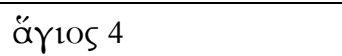 & holy, dedicated \\
\hline & 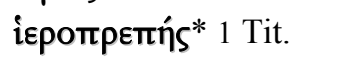 & religious, devoted \\
\hline & öotos 2 Tit. & holy, dedicated \\
\hline \multirow[t]{5}{*}{ 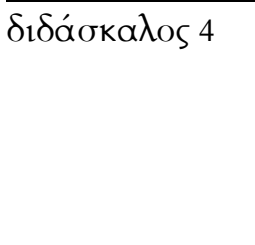 } & $\delta 1 \delta \alpha ́ \sigma k \alpha \lambda$ os 3 & teacher \\
\hline & 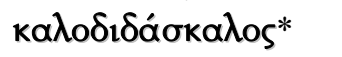 & teacher of what is good \\
\hline & 1 Tit. & \\
\hline & 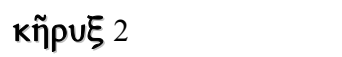 & preacher \\
\hline & 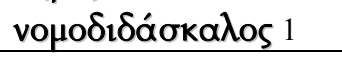 & Teacher of the law \\
\hline \multirow[t]{2}{*}{ 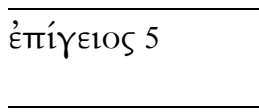 } & & on the earth, human \\
\hline & 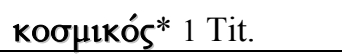 & earthly, worldly \\
\hline tà $\lambda$ oırmá 1 & 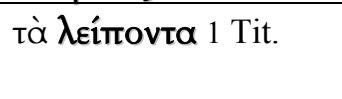 & $\begin{array}{l}\text { lacking, not possessed } \\
\text { the remaining }\end{array}$ \\
\hline \multirow{5}{*}{ 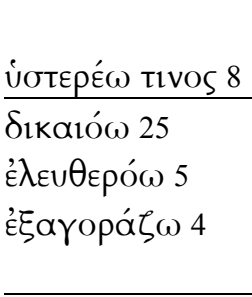 } & $\lambda \varepsilon i ́ \pi \omega^{*}$ tıvos 2 Tit. & $\begin{array}{l}\text { to be in need } \\
\text { to be in need, lack }\end{array}$ \\
\hline & 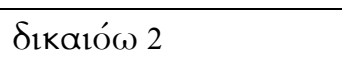 & to put right with \\
\hline & & to set free \\
\hline & & to redeem \\
\hline & $\lambda$ uтрóo $\mu \alpha 1^{*} 1$ Tit. & to liberate \\
\hline \multirow{4}{*}{ 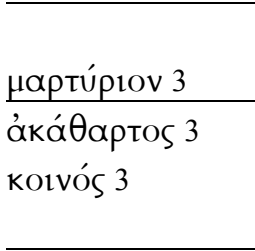 } & 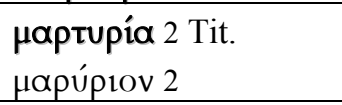 & $\begin{array}{l}\text { witness, testimony } \\
\text { witness, testimony }\end{array}$ \\
\hline & & defiled, unclean \\
\hline & Kolvós 1 & defiled \\
\hline & $\mu \varepsilon \mu 1 \alpha ́ \mu \mu \varepsilon v o S^{*} 1$ Tit. & morally defiled \\
\hline toũ vó & vouıkós* 2 Tit. & $\begin{array}{l}\text { about the law } \\
\text { of the law }\end{array}$ \\
\hline \multirow{3}{*}{ 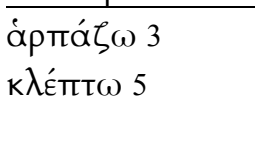 } & & snatch, attack, plunder \\
\hline & & steal \\
\hline & 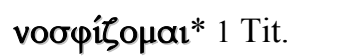 & embezzle \\
\hline \multirow{3}{*}{ 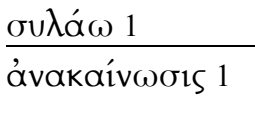 } & & rob \\
\hline & 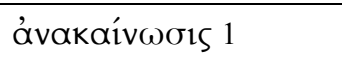 & renewal \\
\hline & $\pi \alpha \lambda_{1 \gamma \gamma \varepsilon v \varepsilon \sigma i \alpha^{*}} 1$ Tit. & rebirth \\
\hline
\end{tabular}


BAUM: Semantic Variation in the Corpus Paulinum

\begin{tabular}{|c|c|c|}
\hline 10 Paulines & 3 Pastoral Epistles & \\
\hline 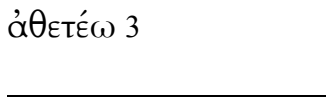 & 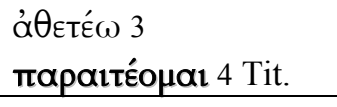 & $\begin{array}{l}\text { to reject, regard as invalid } \\
\text { to reject }\end{array}$ \\
\hline 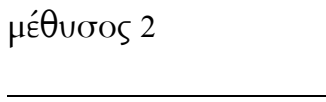 & 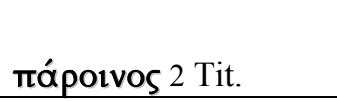 & $\begin{array}{l}\text { drunkard } \\
\text { drunkard }\end{array}$ \\
\hline 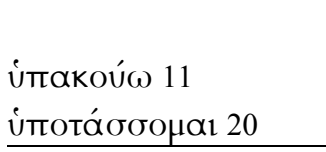 & 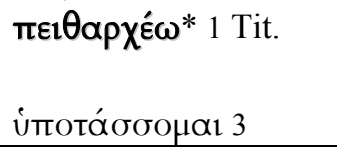 & $\begin{array}{l}\text { to obey } \\
\text { to obey } \\
\text { to bring under control }\end{array}$ \\
\hline ’ós 28 & 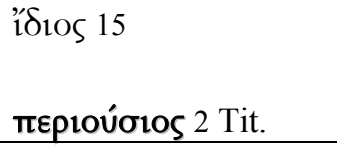 & $\begin{array}{l}\text { one's own, peculiar, } \\
\text { individually } \\
\text { peculiar }\end{array}$ \\
\hline 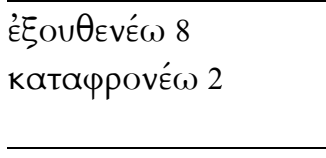 & 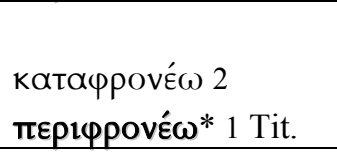 & $\begin{array}{l}\text { despise } \\
\text { despise } \\
\text { disregard }\end{array}$ \\
\hline üprotís 1 & $\begin{array}{l}\pi \lambda \dot{n} \kappa \tau \eta s^{*} 1 \text { Tit. } \\
\text { ußpı́т́́s } 1\end{array}$ & $\begin{array}{l}\text { bully } \\
\text { insolent person, insulter }\end{array}$ \\
\hline 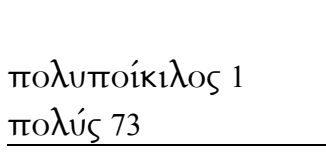 & molkínos 2 Tit. & $\begin{array}{l}\text { of various kinds } \\
\text { manifold } \\
\text { many }\end{array}$ \\
\hline 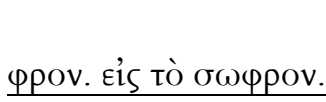 & 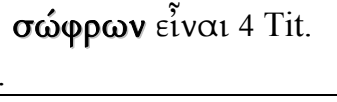 & $\begin{array}{l}\text { to be moderate } \\
\text { to be moderate }\end{array}$ \\
\hline 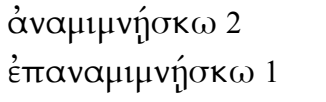 & 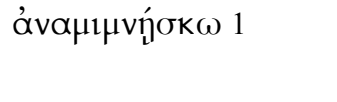 & $\begin{array}{l}\text { cause to remember, remind } \\
\text { to remind }\end{array}$ \\
\hline & 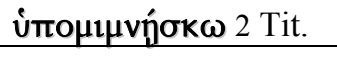 & to remind \\
\hline 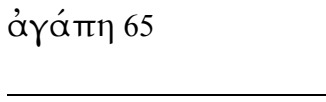 & 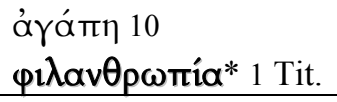 & $\begin{array}{l}\text { love } \\
\text { affection for people }\end{array}$ \\
\hline$\pi \lambda \alpha ́ \operatorname{vos} 1$ & 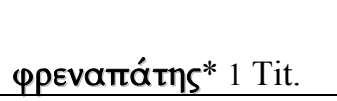 & $\begin{array}{l}\text { deceitful } \\
\text { deceiver }\end{array}$ \\
\hline 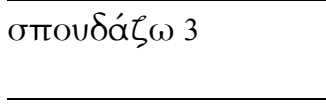 & 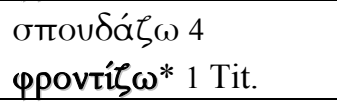 & $\begin{array}{l}\text { to be eager } \\
\text { to keep thinking about, ponder }\end{array}$ \\
\hline $\begin{array}{l}\sigma \cup \mu \varphi^{\prime} \rho \omega 5 \\
\omega \varphi \varepsilon \lambda \varepsilon \dot{\varepsilon} 4\end{array}$ & 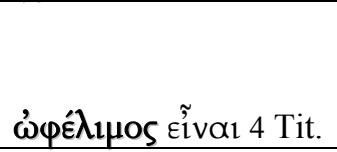 & $\begin{array}{l}\text { to be advantageous } \\
\text { to help, accomplish } \\
\text { to be beneficial }\end{array}$ \\
\hline
\end{tabular}

Of the roughly eighty Pastoral letter words of Titus (printed in bold) seventy are relatively close synonyms to the vocabulary of the ten Paulines. Exceptions include some proper nouns as well as a couple of terms closely related to special subjects like $\gamma \varepsilon v \varepsilon \alpha \lambda$ oría or $\mu \tilde{u} \theta$ os. 


\subsection{The Semantic Relationship between the Pastoral Epistles and the Ten Paulines}

In order to get a better impression of the distinctive vocabulary of the Pastoral Epistles, I choose two paragraphs with a percentage of distinctive words that is far above average. All the words that occur only in the Pastoral Epistles within the Corpus Paulinum (the words in red in Harrison's book) have been highlighted by bold print, e.g. ámé $\lambda_{\imath}$ mov. Words that only occur in Titus, but not in the other twelve Pauline Epistles are marked with an asterisk, e.g. $\lambda$ eínovta*. After each distinctive word, the frequency of its occurrence in the Pastoral

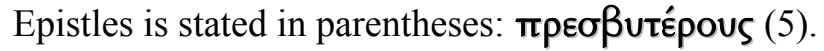

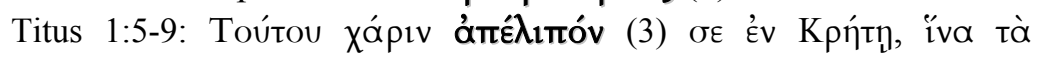

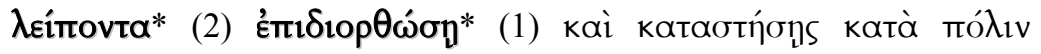

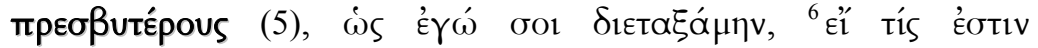

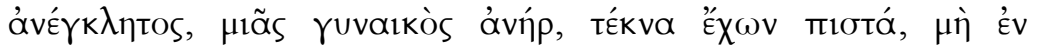

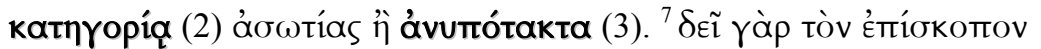

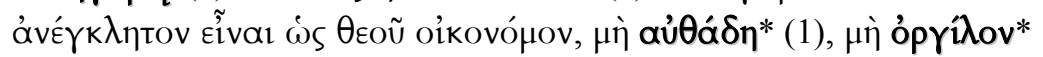

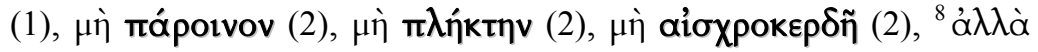

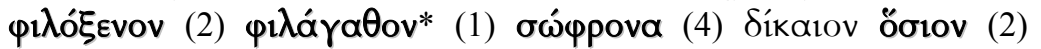

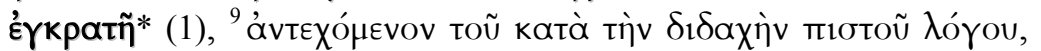

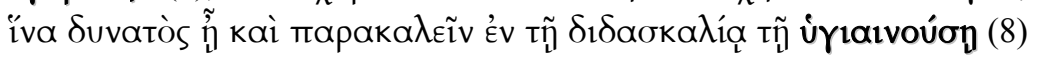

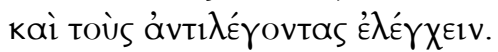

This pericope taken from the Pastoral Epistles can be brought in line with the semantics of the ten Paulines by substituting the majority of the bold-printed distinctive vocabulary with words from the above list of pragmatic synonyms taken from the ten other Paulines. These synonyms have been underlined below. By means of this simple change, the amount of distinctive vocabulary decreases in Titus 1:5-9 from seventeen words to five words or (in terms of percentage) from twenty-one percent to six percent.

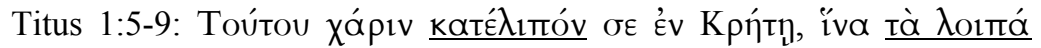

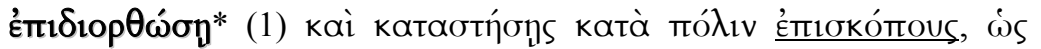

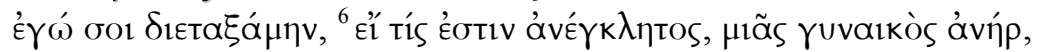

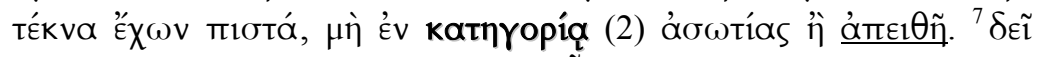

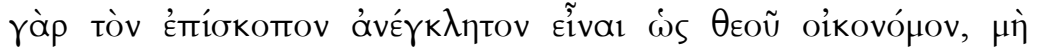

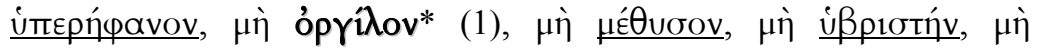

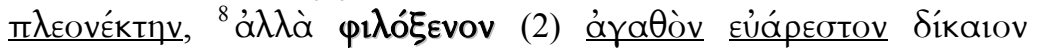

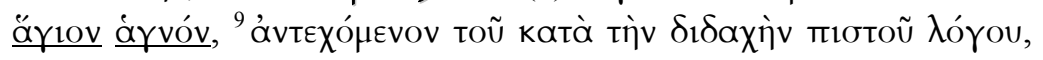




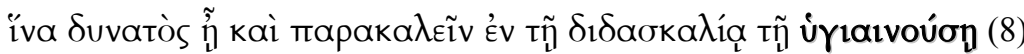

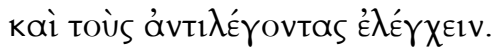

The second example is taken from Titus 3:8-11:

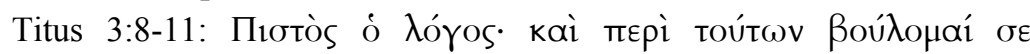

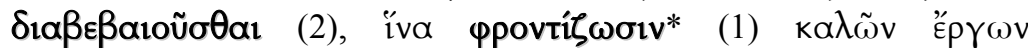

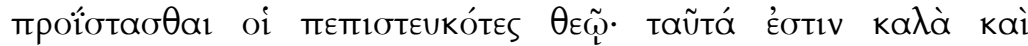

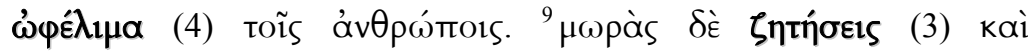

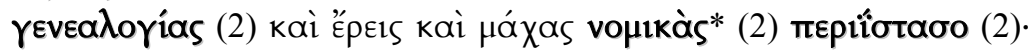

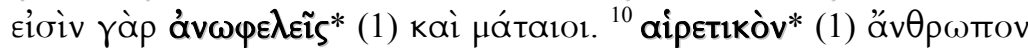

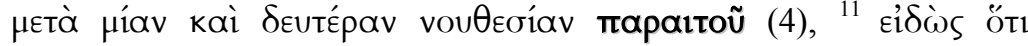

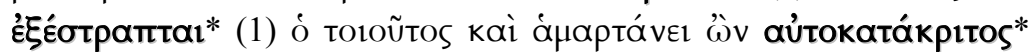
(1).

After replacing the majority of distinctive vocabulary with synonyms from the ten Paulines, the percentage of distinctive words in Titus 3:811 is no longer twenty-one percent, but rather five percent.

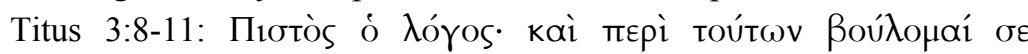

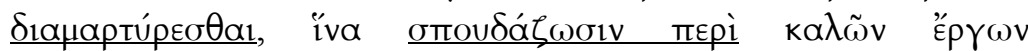

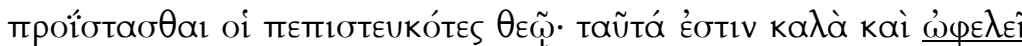

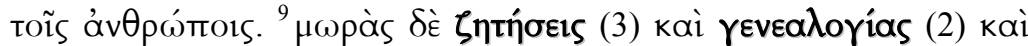

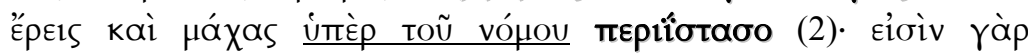

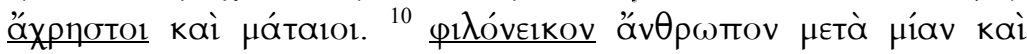

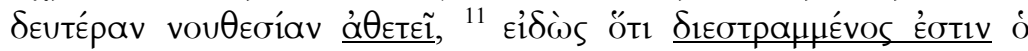

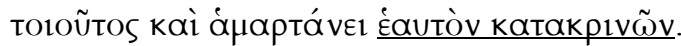

In the same way one could largely free the whole Epistle to Titus as well as the two Epistles to Timothy from their distinct words with the help of the vocabulary of the ten Paulines. One may thin out the comparatively rich vocabulary of the Pastoral Epistles with little effort, so that it correlates in its type-token-ratio to the other ten Paulines.

\section{The Stylistic Peculiarities of the Pastoral Epistles from a Linguistic Perspective}

It goes without saying that these findings, in and of themselves, offer no answer to the question of authorship of the Pastoral Epistles. ${ }^{13}$ Vocabulary statistics are simply inadequate to that task. Rather, I hope to show that the semantic peculiarities of the Pastorals Epistles, viewed

13 For a recent overview of the current debate (especially in the commentaries) cf. J. Herzer in ThLZ 192 (2004): 1267-82. 
as part of the Corpus Paulinum, may be reasonably interpreted with the help of some recently developed categories of linguistics. It seems to me that the distinction that modern linguistic research has drawn between oral and written speech is especially relevant for our purposes. It may shed new light on the characteristic features which cause the three Pastoral Epistles to appear to be different from the other Pauline Epistles. In what follows, I want to apply the semantic data as presented above to a cognate thesis about Pauline syntax $(2: 1)$ and offer my own provisional thesis regarding Pauline vocabulary (2:2). What follows is a short reflection on the peculiar usage of noninflected words in the Corpus Paulinum (2:3).

\subsection{Retrospect: Pauline Syntax}

M. Reiser's thought-provoking article 'Paulus als Stilist' provided the stimulus for the following linguistic interpretation regarding the semantic richness of the Pastorals. The Pauline Epistles feature several parentheses (independent insertions that break up the construction of the super ordinate sentence ${ }^{14}$ ) as well as several instances of anacoluthon (inadequate execution of sentence structure ${ }^{15}$ ). The deficiencies of Pauline syntax, resented even by ancient readers like Origen, are interpreted by Reiser on the basis of linguistic research as typical characteristics of orality. He writes, Paul 'wrote down something that no one before him had ever wanted to write down: ... spoken language of a competent speaker with the typical characteristics of spontaneous speech'. ${ }^{16}$

Beginning in the 1960s linguistic research has intensified its study of orality. Through detailed comparisons with written language the peculiarities of both forms of communication have been further explored. Sudden breaks in sentence structure as well as shifts within the syntactical construction (especially the occurrence of anacoluthon and parenthesis) have been identified as typical features of oral communication. These findings belong to the generally accepted results

14 Cf. BDR $\S 465$.

15 Cf. BDR § 466-70.

16 M. Reiser, 'Paulus als Stilist', SEA 22 (2001): 151-65, here 157. 
of linguistic research on orality ${ }^{17}$ and are relevant for the stylistic analysis of Paul's letters, as Reiser's observations have shown.

In the Pastoral Epistles, however, we seldom find this irregular and wooden sentence structure visible in the other Pauline letters. ${ }^{18}$ Already Holtzmann has summarised his appropriate observations by saying, 'The characteristic breakdowns of sentence construction that result from an abundance of thoughts are missing'. Holtzmann argued that the sentence structure of the Pastoral Epistles gives the mere illusion of clarity of the sort 'that those works that are mere artificial constructs so often display'. ${ }^{19}$ This far-reaching conclusion is not further supported or substantiated. From a linguistic standpoint, however, the syntactical features allow-strictly speaking-only one conclusion, namely that the correct sentence structure of the Pastoral Epistles is not as close to spoken language as the less regimented sentence structure of the other ten Paulines.

\subsection{Thesis: Pauline Vocabulary}

In the same way the semantic peculiarities of the Pastorals can be explained in terms of the linguistic distinction between spoken and written language. According to modern linguistics, (conceptually) oral communication is generally characterised by little variation in the choice of words or (in technical terms) by a low type-token ratio. ${ }^{20}$ This linguistic insight corresponds exactly to the findings presented above: the relation between vocabulary (types) and semantic inventory (tokens) is different in the Pastoral Epistles than in the other ten Paulines. While Philippians contains only seventy-five distinctive words, 1 Timothy (with approximately the same length) has 129 distinctive words (1:1). And while the ten Paulines only make use of the word ávaбтроф́́ (2/1) to denote lifestyle, the Pastoral Epistles

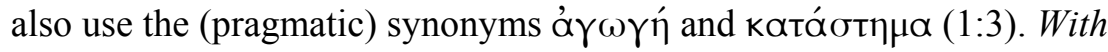

17 Cf. J. Schwitalla, Gesprochenes Deutsch: Eine Einführung (Grundlagen der Germanistik 33; Berlin: Schmidt, 1997): 66-112: 'Syntaktische Kategorien', here 8395.

18 M. Reiser, Sprache und literarische Formen des Neuen Testaments: Eine Einführung (UTB 2197; Paderborn: Schöningh, 2001): 72-74.

19 H. J. Holtzmann, Die Pastoralbriefe, 100-4, here 103.

20 E.g. P. Koch and W. Oesterreicher, 'Schriftlichkeit und Sprache', Schrift und Schriftlichkeit: Ein interdisziplinäres Handbuch internationaler Forschung (Handbücher zur Sprach- und Kommunikationswissenschaft 10/1-2; Berlin: de Gruyter, 1994/96): I, 587-604, here 591. 
their richer semantics, the Pastoral Epistles are closer to (conceptual) writing than the other ten Paulines.

Linguistics gives a simple answer to the question as to why written expressions generally tend to feature richer vocabulary than oral communication. It is assumed that 'the opportunity to use a comparatively rich vocabulary is provided by a sufficient amount of time for composition'. ${ }^{21}$ When someone composes a written text, he usually takes more time and accordingly invests more care in writing than a speaker who expresses himself spontaneously and (due to the lack of time) uses those words that are most familiar to him. Holtzmann has deduced from his observations regarding the vocabulary of the Pastoral Epistles, that the 'personality' of their author may be easily distinguished from Paul's on account of the semantic differences of these letters. ${ }^{22}$ The insights of modern linguistics, however, should lead to a more cautious inference. Our findings with regard to the vocabulary of the Pastoral Epistles only justify the conclusion that their author has expressed himself more carefully and probably had more time at his disposal than the author (or the authors) of the other ten Paulines. Whether the authors of these groups of letters are actually identical or not cannot be decided without considering other (more important) criteria.

\subsection{Prospect: The Non-inflected Words of the Corpus Paulinum}

As far as further stylistic peculiarities of the Pastoral Epistles are concerned, Holtzmann has listed about twenty 'particles' that occur in the ten Paulines, but are missing in the three Pastorals. ${ }^{23}$ Harrison has enlarged this list and mentions 112 'particles'. ${ }^{24}$ Both scholars use the word 'particles' in a general sense as a collective term for non-inflected words, more specifically adverbs, conjunctions, modal particles and prepositions. However, the significance of Harrison's list is limited. First of all, not even twenty of the 112 words listed occur in more than five of the ten Paulines. Secondly, only about thirty of Harrison's

21 P. Koch and W. Oesterreicher, Gesprochene Sprache in der Romania: Französisch, Italienisch, Spanisch (Romanistische Arbeitshefte 31; Tübingen: Niemeyer, 1990): $102-4$.

22 H. J. Holtzmann, Die Pastoralbriefe, 93-100, here 99.

23 H. J. Holtzmann, Die Pastoralbriefe, 100-1.

24 P. N. Harrison, The Problem of the Pastoral Epistles, 36-37. 
'particles' occur at least ten times in the ten letters, which are, taken as a whole, about eight times as long as the Pastoral Epistles.

It is still remarkable, however, that some non-inflected words, which occur in the ten letters some twenty, thirty or forty times, are entirely missing in the Pastorals. In order to evaluate these results, it would be necessary to verify, whether similar peculiarities are visible in other letters or groups of letters within the Corpus Paulinum. To my knowledge, such a crosscheck has never been undertaken.

Incidentally, subsequent to the observations of Holtzmann and Harrison, classicists have unearthed significant insights regarding the usage of particles in Greek literature of the classical and Hellenistic period. It has been shown, for example, that some authors prefer certain particles in dialogical texts, while using other particles primarily in non-dialogical texts. ${ }^{25}$ In light of these and numerous other findings, the undifferentiated and outdated arguments of both Holtzmann and Harrison should no longer be adopted without close scrutiny in Pauline studies. The use of particles in the Corpus Paulinum demands a new and thoroughgoing analysis, which incorporates the latest research in the classics.

\section{Conclusion}

Contrary to some isolated allegations, the vocabulary of the Pastoral Epistles is significantly richer than that of the other ten Paulines. However, the distinctive words of the Pastoral Epistles are for the most part relatively close semantic neighbours or (pragmatic) synonyms to the vocabulary of the other Pauline Epistles. The vocabulary of the Pastorals can easily be made to conform to the (semantically) poorer vocabulary of the ten Paulines by substituting the distinctive words of the Pastoral Epistles with synonyms from the other Paulines. From a linguistic point of view, the semantic richness of the Pastoral Epistles, like their comparatively regular syntax, points to the fact that their author had more time to formulate his texts than the author (or authors) of the other ten Paulines. The style of the Pastoral Epistles is

25 Cf. especially Y. Duhoux, 'Grec écrit et grec parlé. Une étude contrastive des particules aux Ve-IVe siècles' in New Approaches to Greek Particles, ed. A. Rijksbaron (Amsterdam Studies in Classical Philology 7; Amsterdam: Gieben, 1997): 15-48, and the literature listed. 
both syntactically and semantically closer to written language than the style of the other Paulines, which show more characteristics of (conceptual) orality.

The question as to how many different authors actually wrote the thirteen letters of the Corpus Paulinum cannot be answered merely (or even primarily) by means of recourse to style-analytical observations. From a linguistic point of view, both the traditional attribution of the whole Corpus Paulinum to the apostle Paul, as well as the modern theories that attribute about half of the thirteen letters to students of Paul, are compatible with the results above. In the former case one would have to assume that the apostle dictated ten of his letters somewhat spontaneously (without correcting sentence breaks or striving for semantic variety), but invested more time and diligence for writing the three Pastoral Epistles. In the latter case one may conjecture that some students copied the style of six or seven authentically Pauline letters including Paul's 'oral' elements, while another student imitated the (authentic) Pauline style when writing the Pastoral Epistles, yet deleted the typically 'oral' characteristics.

Based on his analysis, Harrison has drawn the conclusion that for stylistic reasons the Pastoral Epistles can by no means be attributed to the same author as the ten other Paulines. ${ }^{26}$ Recent findings of modern linguistics call this thesis into question. The stylistic peculiarities can make no decisive contribution to the argument for deutero-Pauline authorship of the Pastoral Epistles. ${ }^{27}$ Within the context of the discussion of the historical origin of the Pastoral Epistles the linguistic argument should be downgraded to make way for more meaningful criteria.

26 P. N. Harrison, The Problem of the Pastoral Epistles, 84-86: 'Summary of Linguistic Argument', here 85: 'For such a discrepancy within the authentic works of a single author there is at present no known analogy in literature'.

27 Somewhat differently P. C. Spicq, Les Épitres Pastorales (EtB; Paris: Gabalda, 1969): I, 179-200, who concluded: 'The only important argument ... is the argument of style and especially of vocabulary' (179). 